\title{
Climate change and large-scale degradation of spruce: common pattern across the globe
}

\author{
Sanjay Kr. Uniyal ${ }^{1, *}$, Anjali Uniyal ${ }^{2}$ \\ ${ }^{1}$ Biodiversity Division, Institute of Himalayan Bioresource Technology (CSIR), PO Box \#6, Palampur 176061, \\ Himachal Pradesh, India \\ ${ }^{2}$ Department of Habitat Ecology, Wildlife Institute of India, PO Box \#18, Chandrabani, Dehradun 248001, Uttarakhand, India
}

\begin{abstract}
Massive degradation of spruce Picea spp. forests, due to increased temperatures, has been reported from many parts of the world. We have detected large-scale yellowing of Picea smithiana Boiss. in the western Himalayas, where temperatures have increased by $0.6^{\circ} \mathrm{C}$ in the last 3 decades. Large-scale degradation of $P$. smithiana has never been observed in the Himalayan region to date.
\end{abstract}

KEY WORDS: Picea smithiana - Spruce · Himalayas · Forest conservation - Global warming · Temperature Resale or republication not permitted without written consent of the publisher

Forests of spruce Picea spp. are widely distributed in the Northern Hemisphere between $71^{\circ} \mathrm{N}$ in North America to $23^{\circ} \mathrm{N}$ in Southeast Asia (Mark et al. 2007). Spruce has great ecological and economic importance and is receiving high conservation attention. Globally, climate change affects growth and distribution of spruce forests (Tallantire 1972, Barber et al. 2000). Degradation of spruce forests, due to pest attacks, primarily Ips typographus, Pityogenes chalcoprahus, Polygraphus poligraphus and Rhizosphaera kalkhoffii, has been reported from Slovakia (Jakuš 1998), Japan (Yamaoka et al. 2000), Germany (Siefermann-Harms et al. 2004), Poland (Grodzki 2004), France (Gilbert et al. 2005), Slovenia (Jurc et al. 2006), Sweden (Jönsson et al. 2007), Norway (Diamandis 1978), Canada (Gray 2008) and Turkey (Sariyildiz et al. 2008). In Alaska alone more than 450000 ha of spruce forest is severely damaged as a result of infestation by Dendroctonus rufipennis (Werner et al. 2006). Though diseases in spruce have been reported earlier, their intensity and frequency have now increased manifold. Spruce diseases in different parts of the world have been linked to increasing winter temperatures and erratic weather conditions (Jurc et al. 2006).
Until recently, reports of spruce degradation were primarily limited to Europe and America. Large-scale yellowing of Picea smithiana Boiss. was observed during 2008 for the first time in the western Himalayas. The needles of $P$. smithiana turn yellow, giving the tree a charred appearance (Fig. 1). More than 160 ha of good Picea forest is under heavy infestation, and at many places the symptoms are just starting to appear. Increased activities and range expansion of pests due to rising temperatures and other environmental changes have been reported from UK, Australia, Switzerland, China and Spain (Collier et al. 1991, Cannon 1998, Roques et al. 2003, Hódar \& Zamora 2004, Greenslade 2008, Wermelinger et al. 2008) (Fig. 2).

During the last 3 decades, temperature increases have been recorded at a Himalayan weather station near the site of spruce infection. Mean monthly temperature has increased, by $0.13^{\circ} \mathrm{C}$ in September to $1.53^{\circ} \mathrm{C}$ in February, from $1979-1988$ to $1999-2008$ (Fig. 3). On the other hand, the months of June, July and August have shown a decrease in temperature; these are months of heavy rainfall in the area. The number of rainy days in the area has increased from 

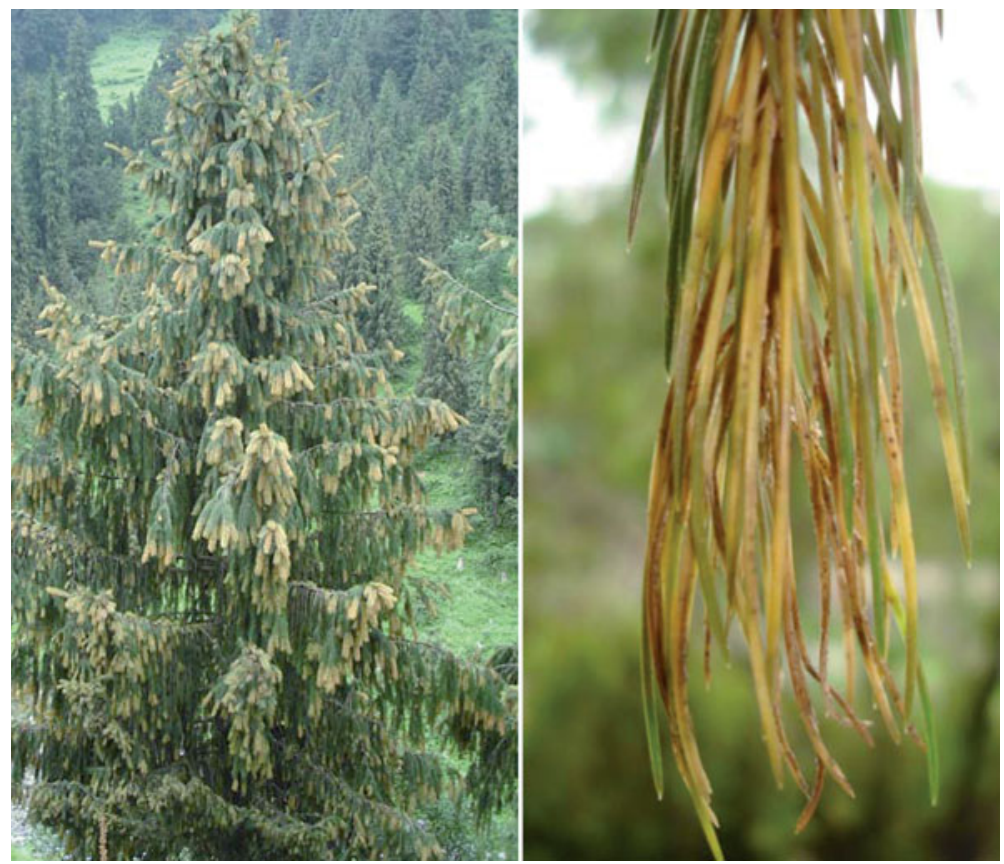

Fig. 1. Picea smithiana. Left: yellowing needles; right: closeup of yellowing
$97 \mathrm{~d} \mathrm{yr}^{-1}$ in 1999 to $111 \mathrm{~d} \mathrm{yr}^{-1}$ in 2007, thus favouring a general cooling during these months. Overall, mean annual temperature has increased from $17.95 \pm 1.59^{\circ} \mathrm{C}$ in the decade $1979-1988$ to $18.55 \pm 1.42^{\circ} \mathrm{C}$ in the decade 1999-2008. Winter temperature increase can be fatal for spruce, as it makes it susceptible to pest attacks (Jackson et al. 2007). Large-scale yellowing of spruce in the Himalayan region is of great concern, as the Himalayas not only shape the climate regime of Asia, but also support the livelihood of nearly 60 million people. Forests of $P$. smithiana play an important role in the hydrology of the mountain ecosystem (Negi 2002) and are of immense importance in harbouring and sustaining native plant diversity. Also, since similar patterns of spruce degradation have been reported across the globe (Fig. 2), spruce appears to be a potent indicator species of changing environmental conditions.

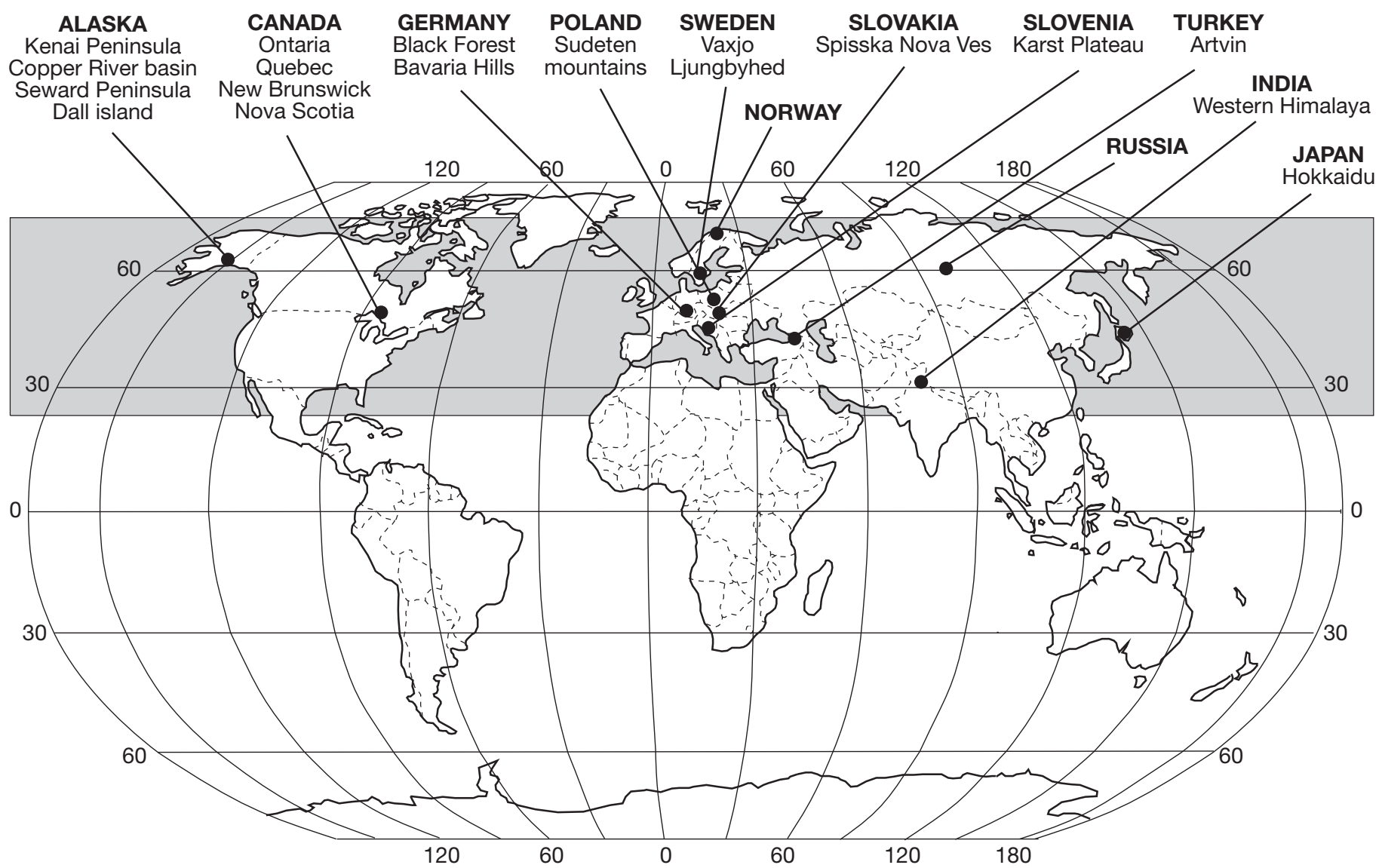

Fig. 2. Areas of reported spruce degradation . Grey: range of spruce 


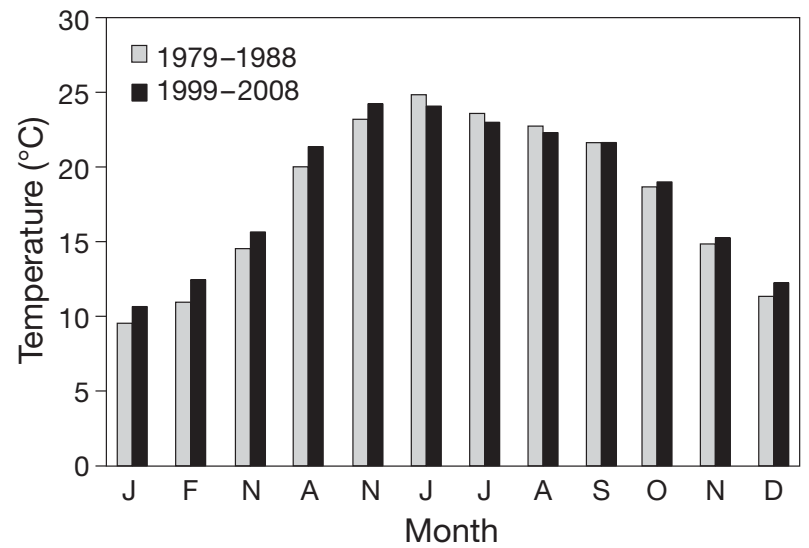

Fig. 3. Mean monthly temperatures near the site of severe spruce yellowing

Acknowledgements. A.U. thanks the Department of Science and Technology, Government of India for financial support under the Women Scientist Scheme vide SR/WOS-A/LS72/2007. Dr. R. D. Singh is thanked for fruitful discussions. We acknowledge the constructive comments of N. C. Stenseth on the earlier version of the manuscript. This is IHBT communication number 0863.

\section{LITERATURE CITED}

Barber VA, Juday GP, Finney BP (2000) Reduced growth of Alaskan white spruce in the twentieth century from temperature-induced drought stress. Nature 405:668-673

Cannon RJC (1998) The implications of predicted climate change for insect pests in the UK, with emphasis on nonindigenous species. Glob Change Biol 4:785-796

Collier RH, Finch S, Phelps K, Thompson R (1991) Possible impact of global warming on cabbage root fly (Delia radicum) activity in the UK. Ann Appl Biol 118:261-271

Diamandis S (1978) 'Top-dying' of Norway spruce, Picea abies (L.) Karst. with special reference to Rhizosphaera kalkhoffii Bubák. Eur J Forest Pathol 8:337-345

Gilbert M, Nageleisen LM, Franklin A, Grégoire JC (2005) Post-storm surveys reveal large-scale spatial patterns and influences of site factors, forest structure and diversity in endemic bark-beetle populations. Landscape Ecol 20: 35-49

Gray DR (2008) The relationship between climate and outbreak characteristics of the spruce budworm in eastern Canada. Clim Change 87:361-383

Greenslade P (2008) Climate variability, biological control and an insect pest outbreak on Australia's Coral Sea islets:

Editorial responsibility: Nils Chr. Stenseth, Oslo, Norway lessons for invertebrate conservation. J Insect Conserv 12:333-342

> Grodzki W (2004) Some reactions of Ips typographus (L.) (Col.: Scolytidae) to changing breeding conditions in a forest decline area in the Sudeten Mountains, Poland. J Pest Sci 77:43-48

> Hódar JA, Zamora R (2004) Herbivory and climatic warming: a Mediterranean outbreaking caterpillar attacks a relict, boreal pine species. Biodivers Conserv 13:493-500

Jakuš R (1998) Types of bark beetle (Coleoptera: Scolytidae) infestation in spruce forest stands affected by air pollution, bark beetle outbreak and honey fungus (Armillaria mellea). Anz Schaedlkd Pflanzenschutz Umweltschutz 71: 41-49

Jönsson AM, Harding S, Bärring L, Ravn HP (2007) Impact of climate change on the population dynamics of Ips typographus in southern Sweden. Agric For Meteorol 146:70-81

Jurc M, Perko M, Džeroski S, Demšar D, Hrašovec B (2006) Spruce barke beetles (Ips typographus, Col.: Scolytidae) in the Dinaric mountain forests of Slovenia: monitoring and modeling. Ecol Model 194:219-226

Mark GT, Boratyński A, Bugała W (2007) Biology and ecology of Norway spruce. Springer, Dordrecht

Negi GCS (2002) Hydrological research in the Indian Himalayan Mountains: soil and water conservation. Curr Sci 83:974-980

> Roques A, Sun JH, Auger-Rozenberg MA, Hua O (2003) Potential invasion of China by exotic insect pests associated with tree seeds. Biodivers Conserv 12:2195-2210

Sariyildiz T, Akkuzu E, Küçük M, Duman A, Aksu Y (2008) Effects of Ips typographus (L.) damage on litter quality and decomposition rates of oriental spruce [Picea Orientalis (L.) Link.] in Hatila Valley National Park, Turkey. Eur J For Res 127:429-440

Siefermann-Harms D, Boxer-Baldoma C, Wilpert K, Heuman $\mathrm{H}$ (2004) The rapid yellowing of spruce at a mountain site in the central Black forest (Germany). Combined effects of $\mathrm{Mg}$ deficiency and ozone on biochemical, physiological and structural properties of the chloroplasts. J Plant Physiol 161:423-437

> Tallantire PA (1972) Spread of spruce (Picea abies (L.) Karst) in Fennoscandia and possible climatic implications. Nature 236:64-65

> Wermelinger B, Rigling A, Schneider Mathis D, Dobbertin M (2008) Assessing the role of bark- and wood-boring insects in the decline of Scots pine (Pinus sylvestris) in the Swiss Rhone valley. Ecol Entomol 33:239-249

> Werner RA, Holsten EW, Matsuoka SM, Burnside RE (2006) Spruce beetles and forest ecosystems in south-central Alaska: a review of 30 years of research. For Ecol Manag 227:195-206

> Yamaoka Y, Takahashi I, Iguchi K (2000) Virulence of ophiostomatoid fungi associated with the spruce bark beetle Ips typographus f. japonicus in Yezo spruce. J For Res 5:87-94

Submitted: January 19, 2009; Accepted: January 30, 2009 Proofs received from author(s): March 20, 2009 